\title{
Overlapping Contests and Middle East International Relations: The Return of the Weak Arab State
}

\author{
Bassel F. Salloukh, Lebanese American University, Beirut
}

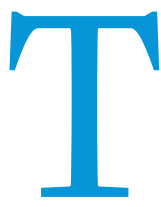

he popular Arab uprisings and the concomitant sectarianization of the region's geopolitical battles intensified the interplay between the domestic and regional levels in the making of Middle East international relations (IR). Material and ideational security threats were intertwined in particularly intense ways, as regimes scrambled to defend both their geopolitical interests and domestic political orders from a mix of local, regional, and transregional actors and ideologies. These patterns are not new, however. In fact, one of the most enduring legacies of what Hudson (2004) labeled "the Montréal school" of Arab politics was its emphasis on the overlap among domestic, transnational, and geopolitical material and immaterial factors in the making of Middle East IR (Brynen 1991; Gause 1992, 2003/4; Korany, Noble, and Brynen 1993; Noble 1991; Salloukh 1996).

Long before the Islamic State in Iraq and Syria (ISIS) exploded into the regional scene, proponents of this school argued that IR theory could ill afford to ignore the overlap among these different factors and levels of analysis. Through a sustained critique of realism's obsession with external material threats and underlying assumption of the state as a unitary rational actor, the Montréal School underscored the stubborn interplay between the domestic and regional levels in the making of Middle East IR. Montréal School theorists (Salloukh and Brynen 2004) identified a number of distinctive patterns of Middle Eastern IR rooted in the interplay among different levels: regimes advancing their geopolitical interests by exploiting the permeability of rival states; transnational movements operating across multiple arenas simultaneously; domestic actors aligning with regional powers to balance against their domestic opponents; and the "omnibalancing" (David 1991) choices facing regime leaders, in which regime security and ideational threats drove foreign-policy choices and regional alliances. In short, there is a long tradition of theorizing how the interplay between the domestic and regional levels served the local agendas of domestic actors and the geopolitical and state-building objectives of many Arab regimes.

In his contribution to this symposium, Valbjørn (2017) asks whether such insights from this long-enduring interplay in the making of Middle East IR contributed to theorybuilding in IR per se. This is less clear; indeed, a 2012 stocktaking of "Domestic Explanations of International Relations"
(Mesquita and Smith 2012) included only one reference to a work pertaining to Middle East IR! ${ }^{1}$ This nonchalance toward theoretical insights generated from the study of the Middle East among general IR theory is a missed opportunity. The return of the weak Arab state after the popular uprisings, and the securitization of hitherto dormant sectarian identities as a result of the interplay between domestic and geopolitical battles, underscores the benefits of theoretical eclecticism in explaining IR in general and its Middle East subtype more specifically. Whether studying the foreign policy or alliance choices of regional actors, the behavior of non-state actors, or the regional system's "persistent permeability" (Salloukh and Brynen 2004) and the use of transregional ideologies as a power resource, it is far more rewarding to travel between theories than to engage in theoretical sectarianism. After all, only a mix of realism's balance of material power, regime-security considerations, and the constructivist emphasis on identity threats can explain puzzling but startling trends in contemporary Middle East IR.

Why, for example, is the Sunni Muslim Brotherhood perceived as a threat by Saudi Arabia but not Qatar, despite both belonging to the same Sunni Gulf monarchical regime type? A material realist explanation offers little traction. By contrast, Riyadh's behavior is driven by its own perceptions and prioritization of ideological threats. On this view, the Muslim Brotherhood's populist brand of political participation threatens core Wahhabi ideological tenets-namely, the tradition of political quietism and absolute obedience to the ruler-on which the stability of the Saudi monarchy is anchored (Rubin 2015). Similarly, as Gause (2017) contends in this symposium, only a combination of regime security and ideational threats explains the curious case of regional underbalancing vis-à-vis Iran by its local opponents: neither realist-driven alliances-joining Saudi Arabia and Israel, Saudi Arabia and Turkey, Turkey and Israel, or Turkey and Egypt-nor a Sunni sectarian-driven alliance-gathering Saudi Arabia, Turkey, Jordan, Egypt, and the other Gulf states-has emerged to balance Iran's obvious geopolitical gains in the wake of the 2003 US invasion and occupation of Iraq. Finally, only the transnational reverberations driven by the ideational permeability of the Arab states system can explain the response of Arab regimes to the overlapping domestic and regional challenges unleashed by the popular uprisings (Lynch 2016). These are only a few post-uprisings puzzles for which a strictly materialist 
realist explanation would lead to a veritable cul-de-sac. By contrast, scholars of Middle East IR have long mastered the art of theoretical eclecticism, deploying any mix of realist, regime-security, and constructivist explanations in a "happy marriage" (Halliday 2005; Hinnebusch 2015). It is time that regional struggles also dominated the politics of the West Bank and Gaza Strip.

The popular uprisings intensified and complicated the contests unleashed by the US invasion of Iraq, exacerbating them in some places (e.g., Lebanon, Yemen, and the West Bank and

\section{In short, there is a long tradition of theorizing how the interplay between the domestic and regional levels served the local agendas of domestic actors and the geopolitical and state-building objectives of many Arab regimes.}

IR theory does the same and, in the process, pays attention to more generalizable theoretical insights generated from the study of Middle East IR.

\section{THE RETURN OF THE WEAK STATE}

The primacy of this type of theoretical eclecticism is best expressed today with the return of the weak Arab state. The US invasion and occupation of Iraq unleashed dynamics that restored the primacy of overlapping domestic and geopolitical battles in Middle East IR. Henceforth, the region became theater for a grand Saudi-Iranian confrontation fought not through classic realist state-to-state military battles but rather through proxy domestic and transnational actors and ideological competition in the domestic politics of a number of weak Arab states, including the perennial candidate Lebanon, the West Bank and Gaza Strip, postwar Iraq, and-to a lesser extent-Yemen and Bahrain (Salloukh 2013). As Gause (2014, 8) carefully noted-for both Riyadh and Tehran, the two main protagonists in this confrontation, but also Qatar and Turkey-the objective "is not to defeat their regional rivals militarily on the battlefield. It is to promote the fortunes of their own clients in these weak-state domestic struggles and thus build up regional influence." Yet, lest we deny them agency, domestic actors also possess their own calculations and interests. They invite, and bandwagon with, regional actors in a bid to balance the political influence of their domestic opponents and advance their own local political interests.
Gaza Strip) and allowing them to spread to new sites-namely, Syria and Libya. As Gause (2017), Matthiesen (2015), Rubin (2014, 2015), and Ryan (2015) admirably demonstrated, the concomitant collapse of some regimes or states and ascendance of old and new political actors with transnational ideologiesthat is, the Muslim Brotherhood, ISIS, and a posse of Salafi or Shi'a non-state actors-restored to center stage the regional system's ideational balancing dynamics. Transnational sectarian identities re-emerged as a potent power resource shaping regime foreign policy and alliance choices, underscoring yet again realism's inability to explain the behavior of Middle East states without recourse to constructivist assumptions (Barnett 1998) and overlapping domestic/geopolitical dynamics. The causality is important: as state authority breaks down, the importance of the elective affinity between co-sectarian state and non-state actors increases. Consequently, Shi'a non-state actors in Lebanon, Iraq, Syria, and Yemen turn to Iran for help, whereas their Sunni counterparts turn to either Saudi Arabia, Turkey, or Qatar (Gause 2017).

The myriad fallouts from the overlapping domestic, regional, and international "struggle for Syria" are examples of this process (Phillips 2016; Ryan 2012). Hafiz al-Assad's once Hobbesian unitary state-which structured political participation and organized state-society relations along populist corporatist and neopatrimonial lines-is in shambles. The breakdown of state institutions and the torpedo of the onetime institutionally strong Syrian state gave way to the emergence of recently securitized sectarian and ethnic identities,

\section{By contrast, scholars of Middle East IR have long mastered the art of theoretical eclecticism, deploying any mix of realist, regime-security, and constructivist explanations in a "happy marriage" (Halliday 2005; Hinnebusch 2015).}

Hazbun's (2017) contribution to this symposium uses Lebanon as a quintessential case for examining such patterns. Lebanon's sectarian elite mastered the game of aligning with external actors against domestic opponents in overlapping domestic and regional struggles. Consequently, Lebanon served as a site for overlapping domestic and geopolitical contests since its creation. By 2006, state collapse and the pull of centrifugal forces in post-Saddam Iraq made the country look increasingly like Lebanon. Overlapping domestic and which in the past had crosscut with more relevant class and regional divisions (Hinnebusch 1991). This transformation of Syria from a Leviathan capable of waging sometimes domestically unpopular but realist geopolitical battles in defense of strategic security interests to a weak state penetrated by regional actors and their sectarian proxies-both transnational and domestic, Salafi-Jihadi or not-unleashed new dynamics that demonstrated the utility of a theoretically eclectic IR toolkit. 
First, the once-unitary Syrian state has been replaced by a weak, penetrated state. A hitherto pivotal player in regional geopolitical battles now serves as a "playground" for these battles. Consequently, neither the unitary nature nor the institutional strength of the state can be taken for granted anymore. Ideological differences among regional states in what constitutes a threat to regime security obviated the emergence of an anti-ISIS balancing alliance in Syria-despite the latter's present and future danger to the security interests of all concerned parties. When such an alliance emerges, it will be driven by domestic regime-security threats rather than

\section{NOTE}

1. The reference is to Etel Solingen (2007).

\section{REFERENCES}

Barnett, Michael C. 1998. Dialogues in Arab Politics: Negotiations in Regional Order. New York: Columbia University Press.

Brynen, Rex. 1991. "Palestine and the Arab State System: Permeability, State Consolidation and the Intifada." Canadian Journal of Political Science 24 (3): 595-621.

David, Steven R. 1991. "Explaining Third World Alignment." World Politics $43(2): 233-56$.

\section{Ideological differences among regional states in what constitutes a threat to regime security obviated the emergence of an anti-ISIS balancing alliance in Syria-despite the latter's present and future danger to the security interests of all concerned parties.}

strictly external geopolitical-power considerations. This does not mean that sectarianism explains more than realism, however. A pan-Sunni alliance among states or non-state actors against Bashar al-Assad's regime also has proved elusive. Instead, different Sunni states sponsor different local Sunni non-state actors in Syria, sometimes with disastrous consequences for their own geopolitical interests. Finally-and despite Iran's evident geopolitical interests in the survival of an allied regime in Syria-Stein (2017) contends in this symposium that neither geopolitical nor sectarian calculations alone can explain Iran's intervention in support of the Assad regime. Instead, he suggests that this process is driven also by the "ideological codependency" between the two regimes, one that is meant to bind the Syrian regime to Tehran but also "reinforces the idea of a counterhegemonic regional security agenda," thereby strengthening the position of the Iranian regime's core hardline elements. All of this suggests the need to combine a mix of realist, regime-security, and constructivist approaches in any attempt to explain Middle East IR.

\section{CONCLUSION}

All of the articles in this symposium call for a recursive conversation between IR theory and Middle East IR. Of course, it would be wrong to assume that the latter has had no impact on mainstream IR theorizing. For example, the more nuanced and sophisticated realist approach assumed in Walt's Taming American Power (2006) is a good example of how studying Middle East IR can have a positive impact on IR theory. The richer analysis undertaken in this book-which expands the arc of strategies available to threatened states to include balancing, balking, binding, blackmail, and delegitimizationis informed substantially by the overlapping domestic and regional consequences of the US invasion of Iraq, thereby broadening the utility and merit of Walt's (1987) original balance-of-threat framework in The Origins of Alliances. Nevertheless, as the articles in this symposium make clear, the current dialogue between these two subdisciplines leaves more cross-fertilization to be desired.
Gause, F. Gregory III. 1992. "Sovereignty, Statecraft and Stability in the Middle East." Journal of International Affairs 45 (2): 441-69.

_ 2003/4. "Balancing What? Threat Perception and Alliance Choice in the Gulf." Security Studies 13 (2): 273-305.

_ 2014. Beyond Sectarianism: New Middle East Cold War. Doha, Qatar: Brookings Doha Center Analysis Paper. Available at www.brookings.edu/ / media/research/files/papers/2014/o7/22\%2obeyond\%2osectarianism\%20 cold\%2owar\%2ogause/english\%2opdf.pdf.

_. 2017. "Ideologies, Alignments and Underbalancing in the New Middle East Cold War." PS: Political Science \& Politics 50 (3): this issue.

Halliday, Fred. 2005. The Middle East in International Relations: Power, Politics and Ideology. Cambridge: Cambridge University Press.

Hazbun, Waleed. 2017. "The Politics of Insecurity in the Arab World: A View from Beirut." PS: Political Science \& Politics 50 (3): this issue.

Hinnebusch, Raymond A. 1991. "Class and State in Ba'thist Syria." In Syria: Society, Culture, and Polity, eds. Richard T. Antoun and Donald Quartet, 29-47 Albany: State University of New York Press.

- 2015. The International Politics of the Middle East, second edition. Manchester, England: Manchester University Press.

Hudson, Michael C. 2004. "American Hegemony and the Changing Terrain of Middle East International Relations." In Persistent Permeability? Regionalism, Localism, and Globalization in the Middle East, eds. Bassel F. Salloukh and Rex Brynen, 163-79. London: Ashgate Publishing Limited.

Korany, Bahgat, Paul Noble, and Rex Brynen (eds.). 1993. The Many Faces of National Security in the Arab World. London: Palgrave Macmillan.

Lynch, Marc. 2016. The New Arab Wars: Uprising and Anarchy in the Middle East. New York: Public Affairs.

Matthiesen, Toby. 2015. "Transnational Identities after the Arab Uprisings." In The Gulf Monarchies beyond the Arab Spring: Changes and Challenges, eds. Luigi Narbone and Martin Lestra, 32-37. Florence, Italy: EUI and Robert Schuman Centre for Advanced Studies. Available at http://cadmus.eui.eu/ bitstream/handle/1814/37734/GulfMonarchies2015.pdf?sequence=1\&is Allowed $=y$.

Mesquita, Bruce Bueno de and Alastair Smith. 2012. "Domestic Explanations of International Relations." Annual Review of Political Science 15: $161-81$.

Noble, Paul C. 1991. "The Arab System: Opportunities, Constraints, and Pressures." In The Foreign Policies of Arab States: The Challenge of Change (second edition), eds. Bahgat Korany and Ali E. Hillal Dessouki, 41-77. Boulder, CO: Westview Press.

Phillips, Christopher. 2016. The Battle for Syria: International Rivalry in the New Middle East. New Haven, CT: Yale University Press.

Rubin, Lawrence. 2014. Islam in the Balance: Ideational Threats in Arab Politics. Palo Alto, CA: Stanford University Press.

- 2015. "Why the Islamic State Won't Become a Normal State." In International Relations Theory and a Changing Middle East. POMEPS. 
Available at http://pomeps.org/wp-content/uploads/2015/o9/POMEPS Studies_16_IR_Web1.pdf.

Ryan, Curtis R. 2012. "The New Arab Cold War and the Struggle for Syria." Middle East Report 262. Available at www.merip.org/mer/mer262/new-arabcold-war-strugglesyria.

—. 2015. "Regime Security and Shifting Alliances in the Middle East." In International Relations Theory and a Changing Middle East. POMEPS. Available at http://pomeps.org/wp-content/uploads/2015/o9/POMEPS Studies_16_IR_Web1.pdf.

Salloukh, Bassel F. 1996. "State Strength, Permeability, and Foreign Policy Behavior: Jordan in Theoretical Perspective." Arab Studies Quarterly 18 (2): 39-65.

- 2013. "The Arab Uprisings and the Geopolitics of the Middle East." The International Spectator 48 (2): 32-46.
Salloukh, Bassel F. and Rex Brynen (eds.). 2004. Persistent Permeability? Regionalism, Localism, and Globalization in the Middle East. London: Ashgate Publishing Limited.

Solingen, Etel. 2007. Nuclear Logics: Contrasting Paths in East Asia and the Middle East. Princeton, NJ: Princeton University Press.

Stein, Ewan. 2017. "Ideological Codependency and Regional Order: Iran, Syria, and the Axis of Refusal." PS: Political Science \& Politics 5o (3): this issue.

Valbjørn, Morten. 2017. "Ideologies for Reviving the IR/Middle East Nexus after the Arab Uprisings." PS: Political Science \& Politics 5o (3): this issue.

Walt, Stephen M. 1987. The Origins of Alliances. Ithaca, NY: Cornell University Press.

2006. Taming American Power: The Global Responses to U.S. Primacy. New York: W.W. Norton \& Company. 